\title{
Bioactive Compounds Content of Chimarrão Infusions Related to the Moisture of Yerba Maté (Ilex Paraguariensis) Leaves
}

\author{
Deborah H. M. Bastos ${ }^{*}$, Ana Claudia Fornari, Yara S. Queiroz and Elizabeth A. F. S. Torres \\ Departamento de Nutrição; Faculdade de Saúde Pública; Universidade de São Paulo; Av. Dr. Arnaldo, 715; \\ dmbastos@usp.br; 01246-904; São Paulo - SP - Brasil
}

\begin{abstract}
The aim of this study was to evaluate the effects of the processing stages of yerba mate (Ilex paraguariensis) on the moisture content of the leaves and the efficiency of the aqueous extraction of some bioactive substances. Samples of yerba maté were analyzed for caffeine, phenolic acids (caffeic acid, 5-caffeoilquinic acid) and flavonoids (quercetin, kaempferol and myricetin) by HPLC equipped with a diode array detector. Processing widely influenced the caffeine and 5-caffeoilquinic acid content of the aqueous extract $(p<0.05)$, which was related to the moisture content of the leaves. Caffeic acid was present in $45 \%$ of the in infusions from dried mate leaves. Quercetin, myricetin and kaempferol were not detected.
\end{abstract}

Key words: Yerba maté (Ilex paraguariensis), processing, bioactive substances

\section{INTRODUCTION}

Yerba maté was being consumed by native South American Indians when the new world was discovered by the European people. Native South Americans were aware of yerba maté's stimulating properties due to caffeine. Nowadays, yerba maté beverages are also recognized as a rich source of antioxidant substances, the phenolic acids (Carini et al., 1998; Clifford and Ramirez-Martinez, 1990; Filip et al., 2000; Mazzafera, 1997), which are readily absorbed by the body (Bravo, 1998; Olthof et al., 2001; Olthof et al., 2003) and are responsible for the in vitro and in vivo antioxidant effect of these beverages (Baisch et al., 1998; Bracesco et al., 2003). Other physiological effects of yerba maté have also been reported and explain its popular use as a choleretic beverage, among others (Gugliucci, 1996; Gorzalczany et al., 2001; Gugliucci and Menini, 2002).

The processing of yerba maté consists of three different stages: a) a rapid drying process called "sapeco", aiming to inhibit enzymatic activity and lower the moisture level; b) a partial drying stage, which usually takes place in rotating drums heated by the burning of wood or gas in places called "barbaqua", and c) a further drying and subsequent grinding stage, after which the yerba maté is called "cancheada" (Schmalko and Alzamora, 2001; Esmelindro et al., 2002). Process parameters (time/temperature of the drying stages) differ among diverse producers (Esmelindro et al., 2002; Nunez and Kanzig, 1995), depending greatly on the driers' design and operation. The processed herb is usually a blend of leaves harvested by different producers who form a cooperative to

\footnotetext{
* Author for correspondence
} 
build a common "barbaqua". The "cancheada" herb is used in two beverages, the "chimarrão" (made with hot water) and the "tererê" (made with cold water). Chimarrão is largely consumed by South Americans. Daily consumption ranges from 1.5 to $6 \mathrm{~L}$.

Some authors suggested that fresh maté leaves should be used to produce maté beverages instead of dried leaves because the drying process greatly diminished the caffeine content (Schmalko and Alzamora, 2001; Esmelindro et al., 2002). It would be advantageous for the maté industry that herbal beverages should contain high amounts of phenolic compounds, responsible for antioxidant properties already observed, and caffeine, a stimulating compound. Although drying steps destroy caffeine, it should be verified whether the drying process enhances aqueous extraction. This study aimed at evaluating the effects of the processing stages of yerba maté (Ilex paraguariensis) on the moisture content of the leaves and on the efficiency of the aqueous extraction of some bioactive substances.

\section{MATERIAL AND METHODS}

Plant material employed in this study was composed of leaves (fresh leaves, just harvested from the bushes), partially dried leaves (leaves after the "sapeco" stage) and dried leaves (after the drying in rotating drums and grinding) obtained directly from producers in Paraná, Brazil, between May and June 2003. The samples were kept in a freezer at $-18^{\circ} \mathrm{C}$ until analysis (no longer than 90 days). Fresh leaves were blanched in our laboratory before freezing to inhibit enzymatic activity within $36 \mathrm{~h}$ of harvesting.

Standards (caffeine, 5-caffeoylquinic acid, caffeic acid, kaempferol, quercetin and myricetin) and HPLC grade methanol were obtained from Sigma Chemical Co. (St. Louis, USA), and acetic acid was purchased from Merck (Darmstadt, Germany).

\section{Blanching of yerba maté fresh leaves at the laboratory before freezing}

The fresh leaves were washed with tap water, immersed in boiling water $\left(\sim 97^{\circ} \mathrm{C}\right)$ for one minute and immediately cooled in ice bath. After removing the moisture excess with absorbent paper, the leaves were kept in sealed plastic bags at $-18^{\circ} \mathrm{C}$ until analyses were performed.

\section{Determination of the moisture content of the samples}

The samples were dried to constant weight at $105^{\circ} \mathrm{C}$ in an oven.

\section{Preparation of the infusions (extracts)}

Different maté samples of $3.6 \mathrm{~g}$ of fresh leaves (60\% of moisture content), $1.8 \mathrm{~g}$ of blanched leaves (21\% of moisture content) and $1.5 \mathrm{~g}$ of dried ground leaves ( $6 \%$ of moisture content) were mixed with $30 \mathrm{~mL}$ of ultrapure water at $85^{\circ} \mathrm{C}$ and left for 3 minutes. The infusion was then filtered trough $\mathrm{n}^{\circ} 1$ Whatman filter paper. This procedure was carried out one more time and the extracts were combined to form the analytical sample. Total extraction time was 6 minutes.

\section{Determination of soluble solids}

A measured volume of aqueous extract $(10 \mathrm{~mL})$ was transferred into a tared beaker and evaporated to dryness. The residue was dried to constant weight at $105^{\circ} \mathrm{C}$ in an oven.

\section{Determination of 5-caffeoylquinic acid, caffeic acid and caffeine}

Infusions were analyzed with no other modification than the appropriate dilution to fit the standard curves, as described by several authors (Ewald et al., 1999; Astill et al., 2001; Bispo et al., 2002). A Shimadzu HPLC chromatograph, equipped with an LC-10ATvp quaternary pump, a Rheodyne manual injection valve with a $20 \mu \mathrm{L}$ sample loop and a diode array detector SPD M10AVP, was used for the determinations. All the modules were controlled by a personal computer equipped with the HPLC System Manager software CLASS-VP. A 4.6 x $250 \mathrm{~mm}, 5 \mu \mathrm{m}$ C18 Microsorb column was used for the separation. The analytical determination of caffeine, caffeic acid and 5-cafeoylquinic acid was carried out by means of high-performance liquid chromatography using a two-solvent isocratic elution. The composition of the solvents was: (A) water/acetic acid $(99.5: 0.5 \mathrm{v} / \mathrm{v})$ and (B) methanol. The mobile phase composition was $75 \%$ of solvent $\mathrm{A}$ and $25 \%$ of solvent B. The flow rate was $1 \mathrm{~mL} / \mathrm{min}$. Data were obtained at $272 \mathrm{~nm}$ for caffeine and $323 \mathrm{~nm}$ for phenolic acids. Identification was based on the comparison of the spectra obtained between 250$350 \mathrm{~nm}$ and the retention time of the unknown substances in relation to that of pure standards. Quantification was achieved by external 
calibration, using a five-point curve of different dilutions of a standard solution. Pearson's correlation coefficient (r) was always $>0.99$. Peak purity, which was determined using the average of similarity of the apex $v s$. the upslope spectrum and the apex $v s$. the download spectrum performed by the photodiode array detector, was higher than 0.99 for both compounds.

\section{Determination of flavonols (quercetin, myricetin and kaempferol)}

Aqueous extracts were submitted to acid hydrolysis as described by Matsubara (2001).The flavonoid aglycons were analyzed using the same apparatus and conditions previously described, except that high-performance liquid chromatography was performed using a twosolvent gradient elution. The composition of the solvents was: (A) water/acetic acid $(99.5: 0.5 \mathrm{v} / \mathrm{v})$ and (B) methanol. The mobile phase composition started at $75 \%$ of solvent A and $25 \%$ of solvent B. It was then linearly increased to $30 \%$ of solvent B in $10 \mathrm{~min}$., and the final condition was held for an additional 4 minutes. The flow rate was $1 \mathrm{~mL} / \mathrm{min}$. Data were obtained at $370 \mathrm{~nm}$.

\section{Data analysis}

Statistical analysis was performed using SPSS (version 11.0/2001- SPSS Inc Chicago). Results are presented as means $\pm \mathrm{SD}$. Data were analyzed for statistical significance by ANOVA and Scheffé's test. Significance level was set at $\mathrm{p}<0.05$.

\section{RESULTS AND DISCUSSION}

The moisture content of the leaves varied according to the processing stage. And, as the heat treatment becomes more intense, the amount of soluble solids in the aqueous extract increased. Therefore, the amount of soluble solids depended on the moisture content of the yerba maté sample (Table 1). This could be due to cell disruption, which occured as the heat and the mechanical impact became more intense throughout the processing stages of yerba maté.

The caffeine, 5-caffeoylquinic acid (5-cqa) and caffeic acid content of infusions prepared with fresh leaves are shown in Table 2. Caffeic acid was detected in only $45 \%$ of the dried yerba maté samples, and its content ranged from 2.6 to $5.8 \mu \mathrm{g} / \mathrm{mL}$. The wide range of variation observed for the bioactive compounds in Table 2 was due to environmental conditions, genetic variability, the possible presence of other Ilex species that could have been harvested together with yerba maté and also due to the fact that the age of the tissue and the exposition to light or shadow seemed to influence the amount of bioactive substances in the maté leaves (Mazzafera, 1994; Ashihara and Crozier, 2001; Fernandez et al., 2002; Gulati and Ravindranath, 1996). Despite this variation, there was a significant difference $(\mathrm{p}<0.05)$ in the mean caffeine and 5-cqa content of the infusions, which was related to the processing stage of yerba maté (Table 3).

Quercetin, myricetin or kaempferol were not detected in this study. Matsubara (2001) detected quercetin in amounts comparables to those present in black and green tea and smaller amounts of kaempferol in commercial yerba maté samples from Campinas, Brazil but did not detect myricetin. The presence of flavonols in mate leaves was described by Filip et al (2001).

A linear relationship between the 5-cqa and caffeine content of chimarrão and the soluble solids content was observed $(r=0.95$ for 5 -cqa and $\mathrm{r}=0.89$ for caffeine) (Fig. 1a,b). The determination coefficients $\left(\mathrm{r}^{2}\right)$ were 0.77 and 0.90 for caffeine and 5-cqa respectively ( $\mathrm{p}<0.05)$, indicating that most of the observed behavior (efficiency of the aqueous extraction) could be explained by the studied variable (soluble solids content). Caffeine and 5-cqa content of the infusions increased with the processing stages of yerba maté, indicating that the use of dried leaves for the production of maté beverages was more advantageous than the use of fresh ones.

The caffeine content of infusions prepared with dried yerba maté found in this study was lower than that determined by Mazzafera (1997), who obtained values ranging from 290 to $790 \mu \mathrm{g} / \mathrm{mL}$, and was similar to that found by Clifford and Ramirez-Martinez (1990). It is well known that the parameters involved in the extraction procedure (such as size of leaves and brewing conditions) greatly interfere in the solubility of bioactive compounds, as well as that growing conditions and genetic characteristics highly influence the content of such substances in plants (Astill et al., 2001). 
Table 1 - Processing stage, moisture content and soluble solids content of yerba maté plant material

\begin{tabular}{ccc}
\hline Processing stage & Moisture content $(\boldsymbol{\%})$ & Soluble solids $(\mathbf{m g} / \mathbf{m L})$ \\
\hline Fresh leaves $(\mathrm{n}=24)$ & $58.28^{\mathrm{a}} \pm 7.16$ & $1.60^{\mathrm{a}} \pm 0.63$ \\
After sapeco (partially dried leaves) & $20.99^{\mathrm{b}} \pm 9.17$ & $3.35^{\mathrm{b}} \pm 1.34$ \\
$(\mathrm{n}=15)$ & $6.02^{\mathrm{c}} \pm 1.54$ & $5.99^{\mathrm{c}} \pm 1.16$ \\
Dried/ground leaves $(\mathrm{n}=33)$ & $\mathrm{s})$ & \\
\hline
\end{tabular}

$\mathrm{n}=$ number of analyzed samples. Results are expressed as mean \pm standard deviation

In each colunn, different superscripts indicate significant difference $(\mathrm{p}<0.05)$

Table 2 - Caffeine 5-cqa and caffeic acid content $(\mu \mathrm{g} / \mathrm{mL})$ of chimarrão infusion according to the locality (city), kind of production area (planted or native) and processing stage of yerba maté leaves (fresh leaves, after sapeco and dried leaves) collected in Paraná state, Brazil in 2003

\begin{tabular}{|c|c|c|c|c|c|}
\hline City & $\begin{array}{l}\text { Production } \\
\text { area }\end{array}$ & Processing stage & $\begin{array}{l}\text { 5- CQA } \\
(\mu \mathrm{g} / \mathrm{mL})\end{array}$ & $\begin{array}{l}\text { Caffeine } \\
(\mu \mathrm{g} / \mathrm{mL})\end{array}$ & $\begin{array}{c}\text { Caffeic acid } \\
(\mu \mathrm{g} / \mathrm{mL})\end{array}$ \\
\hline Paulo Frontin & planted & $\begin{array}{l}\text { Fresh leaves }(n=3) \\
\text { After Sapeco }(n=3) \\
\text { Dried/ leaves }(n=3)\end{array}$ & $\begin{array}{l}139.2 \pm 13.1 \\
217.9 \pm 24.6 \\
376.5 \pm 24.2\end{array}$ & $\begin{array}{l}114.1 \pm 12.8 \\
150.5 \pm 20.8 \\
144.6 \pm 15.3\end{array}$ & $\begin{array}{l}\text { nd } \\
\text { nd } \\
5.7 \pm 0.2\end{array}$ \\
\hline & native & $\begin{array}{l}\text { Fresh leaves }(n=3) \\
\text { After Sapeco }(n=3) \\
\text { Dried leaves }(n=3)\end{array}$ & $\begin{array}{c}92.0 \pm 37.2 \\
231.21 \pm 40.5 \\
320.3 \pm 51.5\end{array}$ & $\begin{array}{c}86.4 \pm 26.6 \\
207.1 \pm 58.2 \\
263.0 \pm 42.3\end{array}$ & $\begin{array}{c}\text { nd } \\
\text { nd } \\
2.6 \pm 0.2\end{array}$ \\
\hline Cascavel & planted & $\begin{array}{l}\text { Fresh leaves }(n=3) \\
\text { Dried leaves }(n=6)\end{array}$ & $\begin{array}{c}72.1 \pm 2.2 \\
357.1 \pm 73.7\end{array}$ & $\begin{array}{c}126.3 \pm 3.5 \\
194.8 \pm 11.3\end{array}$ & $\begin{array}{l}\text { nd } \\
\text { nd }\end{array}$ \\
\hline & native & $\begin{array}{l}\text { Fresh leaves }(n=3) \\
\text { After Sapeco }(n=3) \\
\text { Dried leaves }(n=3)\end{array}$ & $\begin{array}{c}88.6 \pm 13.0 \\
108.1 \pm 20.9 \\
245.4 \pm 8.7\end{array}$ & $\begin{array}{c}114.0 \pm 5.9 \\
87.3 \pm 15.6 \\
159.2 \pm 14.3\end{array}$ & $\begin{array}{l}\text { nd } \\
\text { nd } \\
\text { nd }\end{array}$ \\
\hline Santa Maria & planted & $\begin{array}{l}\text { Fresh leaves }(n=3) \\
\text { Dried leaves }(n=9)\end{array}$ & $\begin{array}{c}71.1 \pm 10.0 \\
447.1 \pm 31.0\end{array}$ & $\begin{array}{c}106.7 \pm 10.7 \\
294.0 \pm 20.3\end{array}$ & $\begin{array}{c}\mathrm{nd} \\
4.5 \pm 0.6\end{array}$ \\
\hline & native & $\begin{array}{l}\text { Fresh leaves }(n=3) \\
\text { After Sapeco }(n=3) \\
\text { Dried/ leaves }(n=6)\end{array}$ & $\begin{array}{c}74.0 \pm 30.9 \\
125.3 \pm 14.3 \\
258.6 \pm 31.2\end{array}$ & $\begin{array}{c}108.8 \pm 20.6 \\
88.4 \pm 18.7 \\
157.8 \pm 16.9\end{array}$ & $\begin{array}{c}\text { nd } \\
\text { nd } \\
3.8 \pm 0.2\end{array}$ \\
\hline Pinheiro Fernandes & native & $\begin{array}{l}\text { Fresh leaves }(n=3) \\
\text { After Sapeco }(n=3) \\
\text { Dried leaves }(n=3)\end{array}$ & $\begin{array}{c}59.4 \pm 10.4 \\
69.1 \pm 28.1 \\
243.7 \pm 38.7\end{array}$ & $\begin{array}{c}31.4 \pm 0.4 \\
49.2 \pm 13.7 \\
172.6 \pm 31.6\end{array}$ & $\begin{array}{l}\text { nd } \\
\text { nd } \\
\text { nd }\end{array}$ \\
\hline
\end{tabular}

$\mathrm{n}=$ number of analyzed samples. Results are expressed as mean \pm standard deviation.

nd $=$ not detected

Table 3 - Mean caffeine and 5-cqa content $(\mu \mathrm{g} / \mathrm{mL})$ of chimarrão infusion according to the processing stage

\begin{tabular}{ccc}
\hline Processing stage & $\begin{array}{c}\text { 5-cqa } \\
\mu \mathrm{g} / \mathbf{m L} \text { extract }\end{array}$ & $\begin{array}{c}\text { Caffeine } \\
\boldsymbol{\mu g} / \mathbf{m L} \text { extract }\end{array}$ \\
\hline Fresh leaves $(\mathrm{n}=24)$ & $83.8^{\mathrm{a}} \pm 35.4$ & $99.6^{\mathrm{a}} \pm 33.4$ \\
After sapeco - partially dried leaves) $(\mathrm{n}=15)$ & $150.3^{\mathrm{b}} \pm 69.6$ & $116.5^{\mathrm{a}} \pm 63.1$ \\
Dried/ground leaves $(\mathrm{n}=33)$ & $341.7^{\mathrm{c}} \pm 90.4$ & $211.5^{\mathrm{b}} \pm 64.0$ \\
\hline
\end{tabular}

$\mathrm{n}=$ number of samples. Results are expressed as mean \pm standard deviation. In each column, different superscripts indicate significant difference $(\mathrm{p}<0.05)$. 

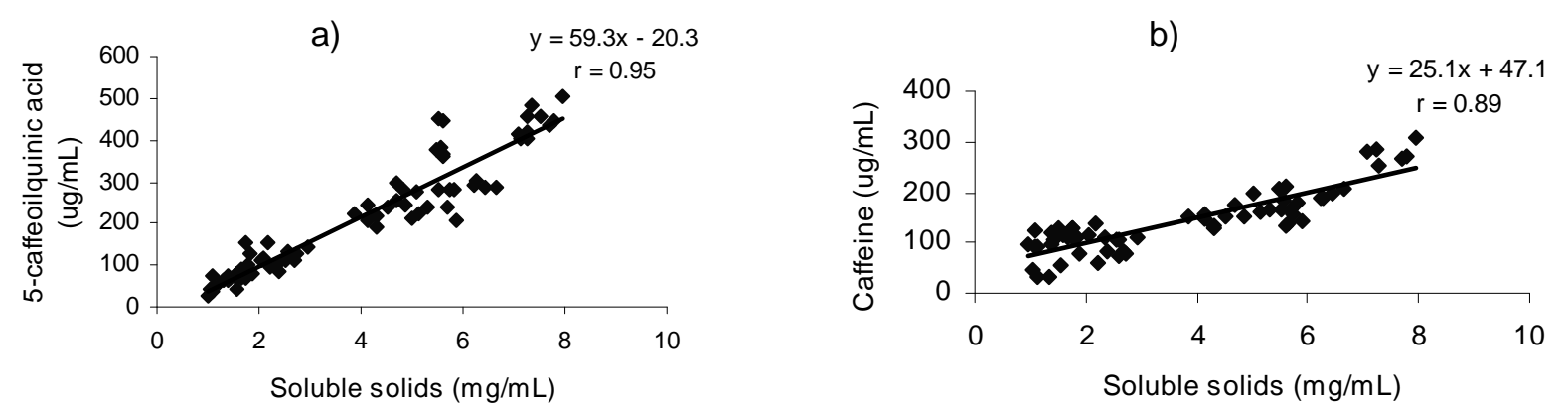

Figure 1 - Relationship between a) the 5-cqa and b) the caffeine content and soluble solids content of chimarrão infusions

The soluble solids content of chimarrão infusions highly depends on the moisture content of maté leaves. Dried yerba maté produced an aqueous extract with higher soluble solids content than the aqueous extract from fresh leaves or partially dried leaves ("sapecada").

\section{CONCLUSION}

There was a linear correlation between the soluble solids content and the bioactive substances of chimarrão, indicating that more efficient extraction resulted in a beverage with greater amounts of 5caffeoilquinic acid and caffeine. Caffeic acid was detected in $45 \%$ of infusions obtained from the dried yerba maté samples analyzed. Yerba maté is an important source of phenolic acids which are absorbed by human and may protect against biological oxidative process, as demonstred by in vivo antioxidant experiments. Therefore, yerba maté consumption should be encouraged.

\section{ACKNOWLEDGMENTS}

The authors are grateful to FAPESP (process $n^{\circ}$ 02/07645-2) for grant-in-aid, and Leão Jr, Paraná, Brazil for grant-in-aid to Ana Claudia Fornari.

\section{RESUMO}

A erva mate (Ilex paraguariensis) é a matéria prima para três tipos de bebidas largamente consumidas na América do Sul. Substâncias bioativas presentes neste produto como a cafeína e os ácidos clorogênicos têm recebido especial atenção da comunidade científica. O objetivo deste trabalho é avaliar o efeito do processamento da erva mate no teor de umidade das folhas e a eficiência da extração aquosa de algumas substâncias bioativas. Amostras de erva mate coletadas no Paraná, Brasil foram objeto deste estudo. Cafeína, ácidos fenólicos (ácido cafeico e ácido 5-cafeoilquinico) e flavonóides (quercitina, miricetina e caempferol) foram analisados por HPLC equipado com detector de arranjo de diodos. Os teores de ácido 5-cafeoilquinico e cafeína do extrato aquoso variam em função da etapa do processamento $(\mathrm{p}<0,05)$, que está relacionada com o teor de umidade das folhas (r $>0,9)$. O ácido cafeico foi determinado em $45 \%$ das infusões obtidas das folhas secas e quercitina, miricetina e caempferol não foram detectados nesses extratos.

\section{REFERENCES}

Ashihara, H. and Crozier, A. (2001), Caffeine: a well known but litlle mentioned compound in plant science. Trends Plant Sci., 6, 407-413.

Astill, C.; Birch, M. R.; Dacombe, C.; Humphrey, P. G. and Martin, P. T. (2001), Factors affecting the caffeine and polyphenol content of black and green tea infusions, J. Agric. Food Chem., 49, 5340-5347.

Baisch, A. L. M.; Johnston, F. L. and Stein, P. (1998), Endothelium-dependent vasorelaxing activity of aqueous extracts of Ilex paraguariensis on mesenteric arterial bed of rats. J. Ethnopharmacol, 60, 133-139. 
Bispo, M. S.; Velosos, M. C. C.; Pinheiro, H. L. C.; De Oliveira, R. F. S.; Reis, J. O. N. and De Andrade, J. B. (2002), Simultaneous determination of caffeine, theobromine and theophyline by high performance liquid chromatography, J. Chromatographic Science, 40, 45-48.

Bracesco, N.; Dell M. R. A.; Behtash S.; Menini T.; Gugliucci A. and Nunes E. (2003), Antioxidant activity of a botanical extract preparation of Ilex paraguariensis: Prevention of DNA double-strand breaks in Saccharomyces cerevisiae an human lowdensity lipoprotein oxidation. J. Altern. Complem. Med., 9, 379-387.

Bravo, L. (1998), Polyphenols: chemistry, dietary sources, metabolism and nutrition significance. Nutr. Rev., 6, 317-333.

Carini, M.; Facino, R. M.; Aldini, M.; Calloni, M. and Colombo, L. (1998), Characterization of phenolic antioxidants from maté (Ilex paraguariensis) by liquid chromatography/mass spectrometry and liquid chromatography/tanden mass espectrometry. Rapid Comm. Mass Spectrom., 12, 1813-1819.

Clifford, M. N. and Ramirez-Martinez, J. R.(1990), Chlorogenic acids and purine alkaloids contents on maté (Ilex paraguaiensis) leaf and beverage. Food Chem., 35, 13-21.

Esmelindro, M. C.; Toniazzo, G.; Waczuck, A.; Dariva, C. and Oliveira, D. (2002), Caracterização físicoquimica da erva-maté: influência das etapas do processamento industrial. Ciênc. Tecnol. Aliment., 22, 193-204.

Ewald, C.; Fjelkner-mMdig, S.; Johansson, K.; Sjholm, I. and Akesson, B. (1999), Effect of processing on major flavonoids in processed onion, green beans, and peas. Food Chem., 64, 231-235.

Fernandez, P. L.; Pablos, F.; Martin, M. J. and Gonzalez, A. G. (2002), Study of catechin and xanthine tea profiles as geographical tracers. J. Agric. Food Chem., 50, 1833-1839.

Filip, R. S.; Lotito, S. B.; Ferraro, G. and Raga, C. G. (2000), Antioxidant activity of Ilex paraguariensis and related species. Nutr. Res., 20, 1437-1446.

Filip, R.; López, P.; Giberti, G.; Coussio, J. and Ferraro, G. (2001), Phenolic compounds in seven south american Ilex species. Fitoterapia, 72, 774-778.

Gorzalczany, S.; Filip, R.; Alonso, M. R.; Mino, J.; Ferraro, G. and Acevedo, C. (2001), Choleretic effect and intestinal propulsion of "maté(Ilex paraguariensis) and its substitutes or adulterants. J.Ethnopharmacol., 75, 201-294.

Gugliucci, A. (1996), Antioxidant effects of Ilex paraguaiensis: Induction of decreased oxidability of human LDL in Vivo. Biochem. Biophys. Res. Comm., 224, 338-344.
Gugliucci, A. and Menini, T. (2002), The botanical extracts of Achyrocline satureoids and Ilex paraguariensis prevent methylglyoxal-induced inhibition of plasminogen and antithrombin III. Life Sciences, 72, 279-292.

Gulati, A. and Ravindranath, S. D. (1996), Seasonal variations in quality of kangra tea (Camellia sinensis (L) O Kuntze) in Himachal Pradesh. J. Sci. Food Agric., 71, 231-236.

Matsubara, S. (2001), Polifenóis em chás comercializados no Brasil., 89 ff. MSc Thesis on Food Science- Faculdade de Engenharia de Alimentos, Universidade Estadual de Campinas, Campinas.

Mazzafera, P. (1994), Caffeine, theobromine and teophylline distribution in Ilex paraguayensis. Rev.Bras.Fisiol.Veg., 6, 149-151.

Mazzafera, P. (1997), Maté drinking: caffeine and phenolic acid intake. Food Chem., 60, 67-71.

Olthof, M. R.; Hollman, P. C. and Katan, M. B. (2001), Chlorogenic acid and caffeic acid are absorbed in humans. J. Nutr., 13, 66-71.

Olthof, M. R.; Hollman P. C. H.; Buijsman, M. N. C. P.; Van Amelsvoort, J. M. .M. and Katan, M. B. (2003), Chlorogenic acid, quercetin-3-rutinoside and black tea phenols are extensively metabolized in humans. J. Nutr., 133, 2692-2692.

Nuñez,J. C. and Känzig, R.G. (1995), Secanza de yerba maté. In: Winge, H.; Ferreira, A. G.; Mariath, J. E. A.; Tarasconi,l, C. (Orgs.). Erva-maté: biologia e cultura no cone sul. Porto Alegre: UFRGS, 175-180.

Schmalko, M. E. and Alzamora, S. M. (2001), Color, chlorophyll, caffeine, and water content variation during yerba maté processing. Dry. Technol., 19, 597-608.
Received: November 03, 2004; Revised: June 10, 2005; Accepted: February 02, 2006. 